\title{
PENINGKATAN KEMAMPUAN MENULIS PUISI MELALUI METODE LATIHAN
}

\author{
NENENG ELIANA \\ PAUD PPs Universitas Negeri Jakarta \\ J1. Rawamangun Muka, Jakarta Timur. E-mail: nenengeliana@yahoo.co.id
}

\begin{abstract}
NENENG ELIANA, THE EFFORTS TO INCREASE POETRY WRITING ABILITY THROUGH PRACTICE METHOD, Action Research in 16 Panjak Common Primary School, Sahan Village, Seluas Sub-district, Bengkayang District, West Borneo Province. The purpose in this research is to find the increase of poetry writing ability through practice method. The research was conducted in 16 Panjak Common Primary School, Sahan Village, Seluas Subdistrict, Bengkayang District, West Borneo Province. The implementation of this research started from February until April 2015 with 37students in the third grade of elementary schools as the subject sampling and one as an observer. The method used in this research is action research referred to action research from Kemmis and Taggart, where's the one cycle of activity consists of 4 components, which are planning, action, monitoring, and reflection. This research consists of 2 cycles with 6 actions. Data analysis in this paper use qualitative and quantitative data. Qualitative data was obtain by monitoring along intervention act-recorded in field research notes and monitoring notes, while quantitative data was obtain by comparing first assessment average score (before action was given) and last assessment score (after action was given). This research finds that there's increasing in ability to write the poetry through practice method. With evidence that there's increasing score, where in first assessment the average score is 5.87, while in the second cycle, the average score is 9.05 out of 12 . This showed an increasing average score by $26 \%$.
\end{abstract}

\section{Key Words: Poetry Writing, Drill Methods}

\begin{abstract}
Abstrak: Penelitian Tindakan di 16 Panjak tertentu Sekolah Dasar Umum, Sahan Desa, Seluas Kecamatan, Kabupaten Bengkayang, Kalimantan Barat Province. Tujuan dalam penelitian ini adalah untuk menemukan peningkatan kemampuan menulis puisi melalui metode latihan. Penelitian ini dilakukan di 16 Panjak tertentu Umum Sekolah Dasar, Sahan Desa, Seluas Kecamatan, Kabupaten Bengkayang, Kalimantan Barat Province. Pelaksanaan penelitian ini dimulai dari Februari hingga April tahun 2015 dengan 37 siswa orang di kelas tiga sekolah dasar sebagai sampel subjek dan satu sebagai pengamat. Metode yang digunakan dalam penelitian ini adalah penelitian tindakan dengan dimaksud dalam penelitian tindakan dari Kemmis dan Taggart, di mana satu siklus kegiatan terdiri dari 4 komponen, yang meliputi yang perencanaan, tindakan, pemantauan, dan refleksi. Penelitian ini terdiri dari 2 siklus dengan memiliki 6 tindakan. Analisis data dalam makalah ini menggunakan menggunakan kualitatif dan data kuantitatif. Data kualitatif adalah mendapatkan dengan memantau sepanjang tindakan intervensi dilakukan melalui tercatat dalam catatan penelitian lapangan dan catatan pemantauan, sedangkan data kuantitatif adalah mendapatkan dengan dengan membandingkan penilaian pertama skor rata-rata skor (sebelum tindakan diberikan) dan skor penilaian terakhir (setelah tindakan diberikan). Hasil penelitian ini menemukan bahwa ada peningkatan kemampuan menulis puisi melalui metode latihan. Dengan bukti bahwa ada peningkatan skor, di mana dalam penilaian pertama skor rata-rata adalah 5.87, sedangkan pada siklus kedua, adalah memperoleh skor rata-rata adalah 9.05 dari skor maksimal adalah dari 12. Ini menunjukkan jika, ada peningkatan skor rata-rata dengan $26 \%$.
\end{abstract}

Kata Kunci: Menulis Puisi, Metode Pelatihan 
Pembelajaran sastra di sekolah dasar sangat beragam. Selain pembelajaran sastra melalui prosa dan drama, terdapat pula pembelajaran satra melalui puisi. Pembelajaran sastra yang mengandung unsur imajinasi dan keindahan dituangkan dalam bentuk bahasa, baik lisan maupun tulisan termasuk ke dalam mata pelajaran bahasa Indonesia.

Kurikulum Tingkat Satuan Pendidikan (2006:324) memuat kompetensi dasar mata pelajaran bahasa Indonesia yang berkaitan dengan pembelajaran sastra melalui puisi, yaitu: (1) membaca puisi dengan lafal, intonasi, dan ekspresi yang tepat, (2) menulis puisi berdasarkan gambar atau benda dengan pilihan kata yang menarik. Berdasarkan kompetensi dasar, guru menyusun indikator pencapaian kompetensi, yaitu: (1) membaca puisi dengan lafal, intonasi, dan ekspresi yang tepat, (2) menjawab pertanyaan yang berkaitan dengan isi puisi, (3) menulis puisi berdasarkan gambar atau benda, (4) menulis puisi berdasarkan pengalaman.
Kompetensi dasar dan indikator pencapaian kompetensi ini tercakup ke dalam aspek keterampilan membaca dan menulis.

Pada umumnya di Sekolah Dasar Negeri 16 Panjak kemampuan siswa dalam membaca puisi sudah cukup baik. Namun kemampuan siswa dalam menulis puisi masih sangat rendah. Hal ini dapat diamati dari hasil tulisan puisi siswa yang mengandung banyak kelemahan dalam tema, pengimajinasian, dan diksi (pilihan kata). Tulisan puisi siswa hanya memiliki satu dari tiga unsur yang seharusnya terdapat pada tema (nada, rasa, dan amanat). Puisi tidak jelas menggambarkan suasana/watak/perilaku. Puisi juga ditulis masih dalam bentuk prosais.

Berdasarkan pengamatan di lapangan, penulis menemukan bahwa kesulitan siswa dalam menulis puisi disebabkan, antara lain oleh rendahnya tingkat penguasaan siswa terhadap kosa kata bahasa Indonesia dan penyajian pembelajaran menulis puisi yang kurang menarik oleh guru. Siswa yang telah banyak memiliki perbendaharaan kata, ia akan dapat 
dengan mudah dan tepat memilih kosa kata yang diperlukan untuk menuangkan ekspresinya dalam bentuk puisi. Namun, bagi siswa yang kurang memiliki perbendaharaan kata, hal ini menjadi masalah baginya. Pada umumnya guru menggunakan metode ceramah dalam pembelajaran puisi. Hal ini menyebabkan rendahnya minat siswa terhadap pembelajaran menulis puisi. Rendahnya minat siswa dalam menulis puisi membawa dampak pada kemampuan menulis puisi siswa.

Berdasarkan latar belakang
masalah di atas, maka dapat
diketahui bahwa penggunaan metode
yang tepat sangat menentukan
pencapaian indikator kompetensi.
Oleh karena itu, penulis berupaya
agar masalah tersebut dapat diatasi,
yakni dengan menerapkan metode
latihan. Penerapan metode latihan
diharapkan dapat meningkatkan
kemampuan menulis puisi pada
siswa kelas III di Sekolah Dasar 16
Panjak.

Berdasarkan latar belakang masalah di atas, maka dapat yang tepat sangat menentukan pencapaian indikator kompetensi. Oleh karena itu, penulis berupaya agar masalah tersebut dapat diatasi, yakni dengan menerapkan metode latihan. Penerapan metode latihan diharapkan dapat meningkatkan Sekolah Dasar 16 Panjak.

\section{Kemampuan Menulis}

Kata kemampuan atau competence dalam bahasa Inggris adalah kesanggupan, kecakapan, dan kekuatan. Sanjaya (2006:17) mengutip definisi competence atau kemampuan menurut Johnson sebagai berikut. "Competency as rational performance which satisfactorily meets the objective for a desired condition." Sementara menurut Hensey (1966:197) kemampuan merupakan pengetahuan, pengalaman dan keterampilan yang dibawa oleh individu atau kelompok pada tugas tertentu.

Berdasarkan pengertian kemampuan di atas dapat dipahami bahwa kemampuan seseorang ditunjukkan oleh unjuk kerja. Unjuk kerja tersebut harus dapat dipertanggungjawabkan dalam upaya mencapai suatu tujuan.

Berkaitan dengan kemampuan, Semiawan, Munandar dan Munandar (1990:1) mengemukakan bahwa kemampuan merupakan daya untuk melakukan suatu tindakan sebagai hasil pembawaan dan latihan. Pendapat ini menjelaskan bahwa 
terdapat dua faktor yang membentuk kemampuan, yakni (1) bawaan, seperti bakat dan (2) latihan, seperti belajar. Sementara Gagne dan Briggs (1979:49) menempatkan kemampuan sebagai hasil belajar (Learning out comes) yang terbagi atas lima kategori yaitu : (1) kemahiran intelektual, (2) informasi verbal, (3) pengaturan kegiatan kognitif, (4) keterampilan motorik, (5) sikap. Pendapat ini menjelaskan bahwa kemampuan yang dimiliki oleh seseorang akan diperoleh dari hasil latihan.

Melihat definisi dan pengertian kemampuan di atas, maka dapat disimpulkan bahwa kemampuan merupakan kesanggupan yang dapat ditunjukkan oleh seseorang sebagai hasil latihan dalam upaya mencapai suatu tujuan. Dalam penelitian ini kemampuan siswa dalam menulis puisi dengan baik merupakan sebagai hasil latihan yang diberikan.

Terdapat beberapa pengertian tentang menulis. Menulis merupakan proses penyampaian pesan kepada pihak lain secara tertulis (Tarigan, 2004:2.61). Menulis dapat diartikan sebagai kegiatan penyampaian pesan (komunikasi) dengan menggunakan bahasa tulis sebagai alat atau medianya (Suparno dan Yunus: 2008). Menulis juga diartikan sebagai keterampilan produktif dengan menggunakan tulisan (Yeti Mulyati, ddk 2007:1.13).

Menurut Graves dalam Suparno dan Yunus (2008:1.4) seseorang enggan menulis karena tidak tahu untuk apa ia menulis dan merasa tidak tahu bagaimana harus menulis. Ketidaksukaan tak lepas dari pengaruh lingkungan keluarga dan masyarakatnya, serta pengalaman pembelajaran menulis atau mengarang di sekolah yang kurang memotivasi dan merangsang minat.

Pendapat di atas mengisyaratkan kepada guru bahwa sangat penting bagi guru untuk menyampaikan tujuan pembelajaran menulis dan mengajarkan bagaimana cara menulis yang baik. Hal ini dapat dicapai apabila guru memiliki kemampuan menulis yang memadai sehingga dapat memotivasi dan menumbuhkan minat siswa terhadap pembelajaran menulis, serta akan 
berdampak pada kemampuan menulis siswa.

Berdasarkan pendapat yang telah dikemukakan di atas dapat dipahami bahwa menulis merupakan kegiatan mengungkapkan pikiran, baik fakta maupun khayal dalam bentuk tulisan dengan tujuan agar dapat dipahami dan dinikmati oleh pembaca. Pembelajaran menulis puisi merupakan suatu sarana bagi siswa untuk menjadikan siswa semakin kreatif dalam menulis.

Kata puisi berasal dari bahasa Yunani, yaitu poiotes yang berarti pembangun, pembentuk, atau pembuat (Slamet Mulyana, 1955:147). Namun, kata puisi mengalami perluasan makna. Kata puisi dapat diartikan sebagai ragam bahasa sastra yang bahasanya terikat oleh irama, matra, rima, serta penyusunan larik dan bait (http://pusatbahasa.depdiknas.go.id/k bbi/index.php). HB Jasin (1967:54) mengungkapkan bahwa puisi adalah pengucapan dengan perasaan yang di dalamnya mengandung pikiranpikiran dan tanggapan-tanggapan. Sementara menurut Watts-Dunton dalam Situmorang (1974:9) puisi adalah ekspresi yang bersifat artistik dari pikiran manusia dalam bahasa emosional dan berirama.

Puisi anak adalah puisi yang sesuai dengan lingkungan anak-anak. Baik dari segi temanya, penggunaan bahasanya, pemakaian katanya, dan berisi nilai-nilai yang bersifat mendidik. Oleh karena itu, tidak jarang puisi anak ini digunakan dalam mengisi syair-syair lagu anakanak (Djago Tarigan, dkk, 2006: 10.42).

Menurut Tarigan, dkk (2006: 10.47) semua bentuk puisi, baik puisi orang dewasa puisi remaja, maupun puisi anak memiliki unsur intrinsik yang dapat dilihat dari dua segi, yakni: a. Dari segi isi puisi terdiri atas: 1) tema; 2) rasa; 3) nada; 4) amanat, b. Dari segi struktur yang terdiri atas: 1) diksi; 2) imajinasi; 3) kata-kata konkret; 4) gaya bahasa; 5) ritme/irama; 6) rima/bunyi. Untuk puisi anak kadangkala tidak terlalu mutlak memenuhi semua unsur di atas karena kesederhanaannya Tarigan, dkk (2006:11.27) juga mengungkapkan bahwa ciri-ciri puisi modern adalah: 1) sangat mementingkan isi, 2) jumlah kalimat 
dan jumlah baris tidak panjang, 3) pilihan kata sangat diutamakan. Terutama kata yang mengandung kekuatan imajinasi, gaya bahasa dan ketepatgunaan kata, 4) persajakan bukan suatu keharusan. Artinya, boleh bersajak sama boleh tidak.

Dalam penelitian ini, penulis memusatkan aspek penilaian pada tema, pengimajinasian, dan diksi (pilihan kata). Tarigan, dkk (2006:10.47-10.48) menjelaskan bahwa yang dimaksud dengan tema pada puisi anak adalah isi keseluruhan puisi yang biasanya terdiri atas pikiran, perasaan, sikap, serta maksud dan tujuan penulisan. Oleh karena itu, tema puisi anak sudah termasuk di dalamnya unsur rasa, nada, dan amanat. Kita dapat dapat melihat tema itu setelah kita mengetahui puisi tersebut secara keseluruhan. Artinya, kalau kita telah mendengar atau membacanya. Pengimajinasian adalah kejelasan daya lukis atau penggambaran penyair mengenai suasana atau keadaan atau watak dan perilaku berdasarkan kata-kata konkret. Penggunaan kata-kata yang konkret bukan hanya nyata atau jelas, tetapi juga padat. Jadi antara pengimajinasian dengan kata-kata konkret merupakan dua unsur yang saling mendukung untuk terciptanya puisi yang baik. Menurut Rosdiana, dkk (2009:7.23) pengimajinasian disajikan dalam beberapa bentuk citraan, yaitu: (1) penglihatan (visual imagery), (2) pendengaran (auditory imagery), (3) penciuman (smell imagery), dan (4) perasaan (tactile imagery).

Berdasarkan paparan di atas dapat disimpulkan bahwa puisi anak merupakan ragam bahasa sastra sebagai hasil ekspresi dan imajinasi seseorang yang memuat tema, imajinasi dan bahasa yang sesuai untuk anak.

Kurikulum Tingkat Satuan Pendidikan 2006 memuat Standar Kompetensi dan Kompetensi Dasar Bahasa Indonesia. Pada kelas III semester 2 dituliskan bahwa Standar Kompetensi Bahasa Indonesia untuk aspek keterampilan menulis adalah mengungkapkan pikiran, perasaan, dan informasi dalam karangan sederhana dan puisi. Sementara pada Kompetensi Dasar Bahasa Indonesia dituliskan bahwa (1) menulis 
karangan sederhana berdasarkan gambar seri menggunakan pilihan kata dan kalimat yang tepat dengan memperhatikan penggunaan ejaan, huruf kapital, dan tanda titik, (2) menulis puisi berdasarkan gambar dengan pilihan kata yang menarik. (KTSP 2006: 324).

Berdasarkan Standar Kompetensi dan Kompetensi Dasar yang dimuat dalam KTSP 2006 kelas III semester 2 maka guru (penulis) menjabarkannya ke dalam indikator pencapaian kompetensi yang dituangkan ke dalam silabus. Adapun indikator pencapaian kompetensi yang berkaitan dengan pembelajaran puisi khususnya ditinjau dari aspek keterampilan menulis yang terdapat dalam silabus, yaitu (1) siswa dapat menulis puisi berdasarkan gambar atau benda, (2) siswa dapat menulis puisi berdasarkan pengalaman. Selanjutnya indikator pencapaian kompetensi ini oleh guru (penulis) pula dituangkan menjadi tujuan pembelajaran dalam Rencana Pelaksanaan Pembelajaran (RPP).

\section{Metode Latihan}

Keberhasilan pencapaian tujuan pembelajaran ditentukan oleh berbagai faktor, antara lain adalah penggunaan metode pembelajaran yang diterapkan oleh guru. Joni dalam Anitah, dkk (2009:1.24) mengemukakan bahwa metode adalah berbagai cara kerja yang bersifat relatif umum yang sesuai untuk mencapai tujuan tertentu. Menurut Anitah, dkk, (2009:1.24) apabila dikaitkan dengan pembelajaran, metode adalah cara yang digunakan guru dalam membelajarkan siswa.

Beragam metode yang sudah dikenal hingga saat ini, seperti metode ceramah, diskusi, tanya jawab, simulasi, pemberian tugas, kerja kelompok, demonstrasi, eksperimen, dan lain sebagainya. Selain metode-metode tersebut, dikenal pula metode drill atau latihan. Menurut Roestiyah N.K (2001:125) metode drill atau metode latihan adalah suatu metode yang membuat siswa melaksanakan kegiatan-kegiatan latihan, agar siswa memiliki ketangkasan atau keterampilan yang lebih tinggi dari 
apa yang telah dipelajari. Roestiyah N.K (2001: 125) juga mengemukakan bahwa tujuan dari latihan adalah agar siswa: (1) memiliki keterampilan motoris, (2) mengembangkan kecakapan intelek, seperti mengalikan, membagi, menjumlahkan, mengurangi, menarik akar dalam mencongak. Mengenal benda/bentuk dalam matematika, ilmu pasti, ilmu kimia, tanda baca dan sebagainya, (3) memiliki kemampuan menghubungkan antara sesuatu keadaan dengan hal lain.

Metode latihan memiliki prinsip dan prosedur dalam proses pembelajaran. Berkenaan dengan prinsip, Popham dan Baker dalam Hadi (2005:73) mengemukakan bahwa penerapan metode latihan mengharuskan guru memberikan kesempatan kepada siswa-siswanya untuk melakukan atau mempraktekkan sesuatu yang sesuai dengan tujuan instruksional. Sementara Hamalik (2008:193-194) mengemukakan bahwa prosedur yang perlu dilakukan oleh guru dalam penerapan metode latihan, yaitu: (1) mempersiapkan diri ke arah kegiatan mengajar, mengikuti suatu versi yang luas sebagaimana yang telah dikembangkan oleh empat langkah Allen (mempertunjukkan/show, menjelaskan/tell, mengerjakan/do, dan memeriksa/check). Dalam versi tersebut ditempuh dua langkah besar, sebelum (before) dan selama (during). "Sebelum" berarti bagaimana mempersiapkan pengajaran dan "selama" berarti bagaimana melaksanakan pengajaran.

Pendapat lain berkenaan dengan prinsip dan prosedur penerapan metode latihan dingkapkan oleh Sudjana (2008), yaitu: (1) peserta didik harus diberi pengertian yang mendalam sebelum diadakan latihan tertentu, (2) latihan untuk pertama kalinya hendaknya diagnosis, mula-mula kurang berhasil kemudian diadakan perbaikan untuk kemudian bisa lebih sempurna, (3) latihan tidak perlu lama asalkan sering dilaksanakan, (4) harus disesuaikan dengan taraf kemampuan peserta didik, (5) proses latihan hendaknya mendahulukan hal-hal yang esensial dan berguna. 
Peningkatan Kemampuan...

Neneng Eliana

Berdasarkan paparan di atas dapat diketahui bahwa metode latihan adalah suatu cara yang dilakukan dengan memberikan serangkaian latihan berulang kepada seseorang hingga mencapai tujuan yang telah ditetapkan.

\section{Penelitian Relevan}

Siti Nadziroh melakukan penelitian yang berkaitan dengan keterampilan menulis puisi bebas melalui metode drill (latihan). Penelitian dilakukan di kelas V MI Ky Ageng Giri Banyumeneng
Mranggen Demak Semester Gasal Tahun Pelajaran 2014/2015.

$$
\text { Penelitian yang berkaitan }
$$
dengan keterampilan menulis puisi juga telah dilakukan oleh Marisa Monika (2014) dengan memanfaatkan lingkungan sebagai sumber belajar. Penelitian dilakukan di kelas V SDN 09 Pontianak Tenggara. Kedua hasil penelitian di atas dapat dilihat pada grafik berikut.

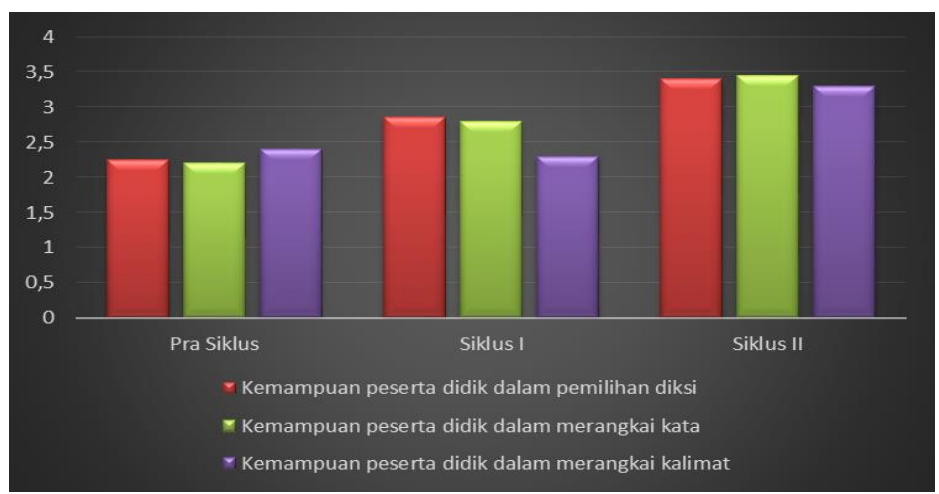

Diagram 1. Hasil Keterampilan Menulis Puisi Bebas Pelajaran Bahasa Indonesia pada Peserta Didik Kelas V MI Ky Ageng Giri Banyumeneng Mranggen Demak melalui Metode Drill 


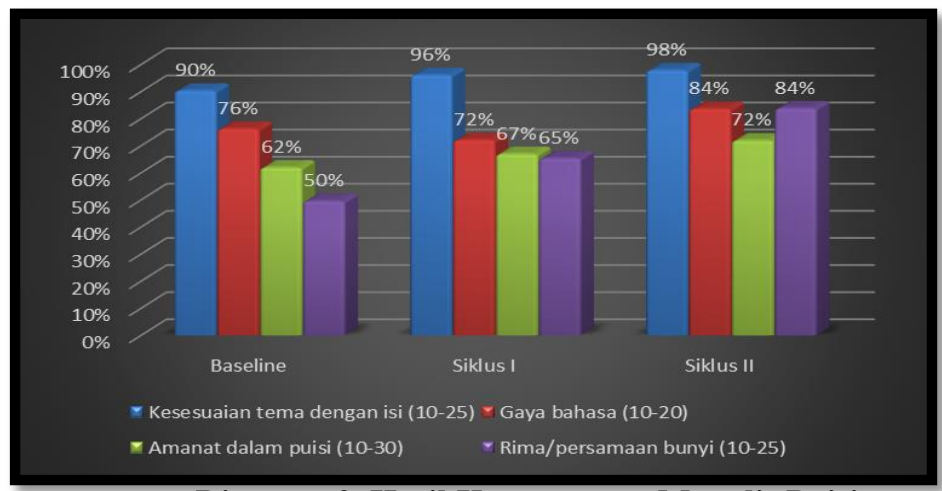

Diagram 2. Hasil Kemampuan Menulis Puisi

dengan Pemanfaatan Lingkungan

sebagai Sumber Belajar di Kelas V

SDN 09 Pontianak Tenggara

Kedua penelitian di atas memiliki perbedaan dengan yang penulis lakukan. Pada penelitian yang dilakukan oleh Siti Nadziroh, perbedaan terdapat pada kegiatan dalam intervensi dan aspek penilaian. Siti Nadziroh memberikan latihan menulis puisi bebas dalam bimbingan kelompok belajar dengan aspek penilaian difokuskan pada diksi, merangkai kata, dan merangkai kalimat. Sementara penulis memberikan latihan dalam kelompok maupun individual dengan aspek penilaian difokuskan pada tema, pengimajinasian, dan diksi. Pada penelitian yang dilakukan oleh Marisa Monika perbedaan terdapat pada variabel $\mathrm{Y}$ dan aspek penilaian. Variabel Y pada penelitian yang dilakukan oleh Marisa Monika adalah pemanfaatan lingkungan sebagai sumber belajar dengan aspek penilaian difokuskan pada tema, gaya bahasa, amanat, dan rima. Sementara variabel $\mathrm{Y}$ yang terdapat pada penelitian penulis adalah metode latihan dengan aspek penilaian difokuskan pada tema (rasa, nada, dan amanat), pengimajinasian, dan diksi.

Kedua penelitian di atas menunjukkan berbagai upaya yang dilakukan oleh guru untuk meningkatkan kemampuan menulis puisi pada siswa. Hasil kedua penelitian di atas menunjukkan pula adanya peningkatan kemampuan menulis puisi pada siswa. 


\section{Tujuan Penelitian}

Penelitian yang dilakukan oleh penulis di Sekolah Dasar Negeri 16 Panjak, Dusun Panjak, Desa Sahan, Kecamatan Seluas, Kabupaten Bengkayang, Provinsi Kalimantan Barat ini bertujuan untuk meningkatkan kemampuan menulis puisi pada siswa kelas III melalui metode latihan.

\section{METODOLOGI PENELITIAN}

Penelitian ini dilakukan di Sekolah Dasar Negeri 16 Panjak, Desa Sahan, Kecamatan Seluas, Kabupaten Bengkayang, Provinsi Kalimantan Barat. Waktu penelitian pada tahun pelajaran 2014/2015 yang dilaksanakan pada bulan Februari sampai dengan bulan April 2015.

Jenis penelitian yang akan digunakan adalah penelitian tindakan kelas (Classroom Action Research) menggunakan pendekatan deskriptif kualitatif. Penelitian ini menggunakan penelitian tindakan model Kemmis dan Taggart. Model penelitian tindakan spiral ini bertujuan untuk memperbaiki atau meningkatkan proses belajar mengajar. Desain intervensi tindakan/rancangan siklus penelitian ini menggunakan model Kemmis dan Taggart (1988:11-14) yang didasarkan atas: (1) perencanaan, (2) tindakan, (3) pengamatan, dan (4) refleksi. Hubungan antara komponen tersebut menunjukkan sebuah siklus atau kegiatan berulang.

Setiap siklus terdiri atas 3 kali pertemuan dengan waktu 2 x 35 menit setiap pertemuan. Pelaksanaannya dilakukan hanya $1 \mathrm{x}$ dalam seminggu agar tidak mengganggu guru untuk mengajarkan materi lainnya.

Penulis dan pengamat menetapkan keberhasilan tindakan ditentukan oleh besarnya persentase kenaikan minimal tindakan dan pencapaian Kriteria Ketuntasan Minimal (KKM) indikator pencapaian kompetensi. Berdasarkan kesepakatan penulis dan pengamat besarnya persentase kenaikan minimal tindakan adalah $20 \%$. Sementara penetapan besarnya KKM indikator pencapaian kompetensi sebesar 66,67. Dalam Kurikulum Tingkat Satuan Pendidikan 2006 perhitungan KKM indikator pencapaian kompetensi didasarkan 
atas pertimbangan tiga kategori, yakni kompleksitas kompetensi, daya dukung yang meliputi sarana dan prasarana, serta intake yang meliputi kemampuan guru dan kemampuan rata-rata siswa. Tiap-tiap kategori diberi rentang skor 1-3. Pada kategori kompleksitas kompetensi, semakin kompleks kompetensi maka skor yang diberikan semakin kecil. Sementara pada kategori daya dukung, semakin baik daya dukung maka skor yang diberikan semakin besar. Demikian pula pada kategori intake, semakin baik kemampuan guru dan kemampuan rata-rata siswa maka skor yang diberikan semakin besar. (Perhitungan KKM indikator pencapaian kompetensi terdapat pada lampiran).

Dalam penelitian ini terdapat dua data, yaitu data pemantau tindakan (proses) dan data penelitian (hasil). Data pemantau tindakan merupakan data yang digunakan untuk mengontrol kesesuaian pelaksanaan dengan rencana tindakan. Sementara data penelitian adalah data tentang fokus penelitian, yakni kemampuan awal siswa dalam menulis puisi yang digunakan untuk keperluan analisis data penelitian, sehingga diperoleh gambaran peningkatan kemampuan menulis puisi pada siswa sekolah dasar kelas III. Sumber data dalam penelitian ini adalah siswa kelas III SDN 16 Panjak yang berjumlah 37 siswa.

Teknik pengumpulan data dalam penelitian ini dilakukan melalui teknik observasi, lembar penilaian, dan alat dokumentasi. Teknik-teknik ini dilakukan sesuai dengan data yang diperlukan dalam penelitian. Observasi dilakukan untuk memperoleh data tentang proses pembelajaran. Instrumen obervasi berupa kolom dimensi pengamatan yang berisi pelaksanaan pembelajaran, aspek pengamatan yang berisi kegiatan guru (penulis) dan siswa, serta kolom keterangan yang berisi ya dan tidak yang harus diisi dengan tanda check list $(\sqrt{ })$ oleh teman sejawat. Penilaian dilakukan melalui unjuk kerja siswa berupa hasil tulisan puisi. Berdasarkan kesepakatan bersama antara guru dan siswa, hasil tulisan puisi siswa didokumentasikan dalam suatu folder sehingga dapat diperoleh data perkembangan siswa dalam menulis 
puisi dari waktu ke waktu. Untuk menghindari subjektivitas penilaian oleh penulis maka penilaian dilakukan oleh dua orang penilai, yaitu penulis dan teman sejawat. Penilaian dilakukan berdasarkan rubrik yang telah dibuat oleh penulis. Rubrik menulis puisi menggunakan skala 1- 4.
Teknik membuat skala menurut Nazir serta Good dan Hatt dalam Sukardi (2011:145) adalah cara mengubah fakta-fakta kualitatif yang melekat pada objek atau subjek penelitian (attribute) menjadi urutan kuantitatif. Berikut adalah tabel ketentuan skala penilaian kemampuan menulis puisi

Tabel 1. Ketentuan Skala Penilaian Kemampuan Menulis Puisi

\begin{tabular}{|c|c|c|c|c|c|}
\hline \multirow{2}{*}{ No } & \multirow{2}{*}{ Aspek Penilaian } & \multicolumn{4}{|c|}{ Kriteria/Skor } \\
\hline & & 4 & 3 & 2 & 1 \\
\hline \multirow[t]{2}{*}{1} & Tema (unsur nada, & Puisi memiliki tiga unsur & Puisi memiliki dua unsur & Puisi memiliki satu unsur & Puisi tidak memiliki unsur \\
\hline & rasa, dan amanat) & yang terdapat pada tema & yang terdapat pada tema & yang terdapat pada tema & yang terdapat pada tema \\
\hline \multirow[t]{3}{*}{2} & Pengimajinasian & Puisi dengan sangat jelas & Puisi dengan jelas & Puisi cukup jelas & Puisi tidak jelas \\
\hline & & menggambarkan suasana/ & menggambarkan suasana/ & menggambarkan suasana/ & menggambarkan suasanal \\
\hline & & watak/perilaku & watak/perilaku & watak/perilaku & watak/perilaku \\
\hline \multirow[t]{3}{*}{3} & Diksi & Puisi ditulis dengan kata & Puisi ditulis dengan kata & Puisi ditulis dengan kata & Puisi ditulis dengan kata \\
\hline & & yang sangat tepat, singkat, & yang tepat, singkat, dan & yang cukup tepat, singkat, & yang tidak tepat, singkat, \\
\hline & & dan padat & & dan padat & dan padat \\
\hline
\end{tabular}

Analisis data penelitian dilakukan dengan menguji hipotesis tindakan, yaitu dengan menggunakan perbedaan nilai rata-rata siswa sebelum memperoleh tindakan dan setelah memperoleh tindakan. Analisis data ini dilakukan dalam setiap siklus dengan menghitung rata-rata skor siswa dan prosentasi kenaikan keberhasilan tindakan. Teknik analisis data yang digunakan bertujuan untuk mengetahui pengaruh pemberian tindakan berupa metode latihan terhadap peningkatan kemampuan menulis puisi pada siswa sekolah dasar kelas III SDN 16 Panjak.

\section{Pelaksanaan Tindakan}

Langkah-langkah kegiatan pada siklus II hampir sama dengan siklus I. Perbedaannya adalah pada siklus I siswa menulis puisi secara berkelompok, sedangkan pada siklus II siswa menulis puisi secara individual. 
Pada kegiatan pembelajaran, guru menyampaikan terlebih dulu tujuan yang akan dicapai dan kegiatan yang akan dilakukan hari itu. Selanjutnya guru mengajukan beberapa pertanyaan yang berkaitan dengan benda-benda sekitar, benda langit, hewan peliharaan, dan kegiatan siswa (dapat melalui gambar). Hal ini dilakukan untuk membantu membangkitkan imajinasi dan memperkaya kosa kata siswa yang diperlukan dalam menulis puisi. Agar siswa lebih memahami puisi yang baik dan yang kurang baik, maka guru menuliskan contoh puisi di papan tulis. Guru menunjukkan kekuatan maupun kelemahan yang terdapat pada puisi. Kemudian siswa ditugaskan membuat puisi (berkelompok/individual). Setelah waktu yang telah ditentukan, secara bergantian tiap-tiap kelompok/individu menuliskan puisi di papan tulis Tiap-tiap kelompok/individu membacakan hasil tulisan puisinya. Pembahasan hasil tulisan puisi secara berkelompok/individual dilakukan dengan menunjukkan kekuatan maupun kelemahan puisi.
Pembahasan ini diawali dengan meminta penilaian antarkelompok/siswa. Diikuti penilaian oleh guru. Bagi kelompok/individu yang sudah dapat menulis puisi dengan baik, mendapat apresiasi dari teman dan guru, yakni dengan memberikan tepuk tangan. Sementara bagi kelompok/individu yang belum mampu membuat puisi dengan baik, mendapat motivasi dari guru. Selanjutnya secara berkelompok/individu, siswa menulis puisi berdasarkan hasil pembahasan. Hasil perbaikan tulisan puisi siswa diserahkan ke guru untuk dinilai dengan pemberian skor oleh guru.

Berdasarkan observasi saat intervensi tindakan diberikan, proses pembelajaran berlangsung sangat baik. Kemampuan guru sangat baik dalam menyajikan materi dan menguasai langkah-langkah pembelajaran sesuai dengan rencana perbaikan pembelajaran yang telah dibuat. Sementara siswa melakukan serangkaian latihan yang diberikan oleh guru. Siswa juga diberi kesempatan untuk membacakan hasil tulisan puisinya dan menilai hasil tulisan puisi teman sekelas. Siswa 
terlihat sangat antusias dalam adalah hasil observasi aktivitas guru mengikuti pembelajaran. Berikut dan siswa dalam pembelajaran.

Tabel 2. Hasil Observasi Aktivitas Guru dan Siswa dalam Pembelajaran

\begin{tabular}{|c|c|c|c|}
\hline \multirow{2}{*}{$\begin{array}{c}\text { Dimensi } \\
\text { Pengamatan }\end{array}$} & \multirow{2}{*}{ Aspek Pengamatan } & \multicolumn{2}{|c|}{ Keterangan } \\
\hline & & $\mathrm{Ya}$ & Tidak \\
\hline \multirow{7}{*}{ Pelaksanaan } & 1. Guru menuliskan contoh tulisan puisi di papan tulis & $\sqrt{ }$ & \\
\hline & 2. Guru menunjukkan kekuatan pada contoh tulisan puisi & $\sqrt{ }$ & \\
\hline & 3. Guru menuliskan contoh tulisan puisi yang kurang baik & $\sqrt{ }$ & \\
\hline & 4. Guru menunjukkan kelemahan pada contoh tulisan puisi & $\sqrt{ }$ & \\
\hline & 5. Siswa menulis puisi & $\sqrt{ }$ & \\
\hline & 6. Siswa menuliskan hasil tulisan puisinya di papan tulis & $\sqrt{ }$ & \\
\hline & 7. Siswa membacakan hasil tulisan puisinya & $\sqrt{ }$ & \\
\hline \multirow[t]{5}{*}{ Pembelajaran } & $\begin{array}{l}\text { 8. Guru memberi kesempatan kepada siswa lain untuk menilai } \\
\text { hasil tulisan puisi temannya yang ditulis di papan tulis }\end{array}$ & $\sqrt{ }$ & \\
\hline & 9. Guru menunjukkan kekuatan pada tulisan puisi siswa & $\sqrt{ }$ & \\
\hline & 10. Guru menunjukkan kelemahan pada tulisan puisi siswa & $\sqrt{ }$ & \\
\hline & 11. Siswa menulis puisi berdasarkan hasil pembahasan & $\sqrt{ }$ & \\
\hline & 12. Guru menilai hasil perbaikan tulisan puisi siswa & $\sqrt{ }$ & \\
\hline
\end{tabular}

\section{HASIL DAN PEMBAHASAN}

Berdasarkan hasil penilaian terhadap kemampuan menulis puisi, hasil asesmen awal menunjukkan bahwa kemampuan siswa dalam menulis puisi masih sangat rendah. Latihan yang diberikan oleh guru (penulis) pada siklus I dan II menambah penguasaan kosa kata dan pemahaman yang mendalam pada siswa dalam menulis puisi dengan baik sehingga mampu meningkatkan kemampuan menulis puisi pada siswa kelas III di Sekolah Dasar Negeri 16 Panjak.

Pada asesmen awal rata-rata skor yang diperoleh siswa hanya sebesar 5,87 (49\%) dari skor maksimal yang ditentukan sebesar 12. Umumnya tulisan puisi siswa memiliki 1 dari 3 unsur yang seharusnya terdapat pada tema. Puisi tidak jelas menggambarkan suasana/watak/perilaku. Puisi ditulis dalam bentuk prosais. Ditinjau dari segi keaktifan, pada umumnya siswa sangat pasif, tidak menunjukkan minat pada pembelajaran menulis puisi.

Rata-rata skor yang diperoleh siswa pada siklus I menunjukkan peningkatan, yakni sebesar 8,22 (69\%). Latihan yang diberikan dalam kelompok membawa pengaruh 
terhadap penguasaan kosa kata anak. Hasil tulisan puisi siswa menunjukkan terjadinya peningkatan. Puisi memiliki 2 dari 3 unsur yang seharusnya terdapat pada tema. Puisi cukup jelas menggambarkan

suasana/watak/perilaku. Namun, pilihan kata masih kurang tepat dan singkat. Ditinjau dari segi keaktifan, sebagian besar siswa sudah aktif, mereka mulai menunjukkan minat pada pembelajaran menulis puisi.

Meskipun hasil yang diperoleh pada siklus I sudah menunjukkan pencapaian kriteria keberhasilan tindakan yang telah ditetapkan sebesar 20\% dan keberhasilan pencapaian KKM indikator pencapaian kompetensi yang telah ditentukan sebesar 66,67, penulis memutuskan melanjutkan intervensi ke siklus II. Hal ini dilakukan karena pada siklus I data yang diperoleh masih dalam bentuk kelompok. Oleh karena itu, untuk memperoleh data kemampuan siswa secara individual diperlukan intervensi lebih lanjut.

Pada siklus II rata-rata skor yang diperoleh siswa sebesar 9,05
(75\%). Latihan serta bimbingan yang diberikan secara secara individual menambah pemahaman yang mendalam pada siswa untuk menulis puisi dengan baik. Umumnya puisi memiliki seluruh unsur yang terdapat pada tema. Puisi dengan jelas menggambarkan

suasana/watak/perilaku. Puisi telah menggunakan kata dengan tepat, singkat, dan padat. Ditinjau dari segi keaktifan, seluruh siswa menunjukkan minat pada pembelajaran menulis puisi.

Berdasarkan rata-rata skor yang diperoleh dari asesmen awal dan akhir, maka dapat diketahui telah terjadi peningkatan rata-rata skor sebesar 3,18 (26\%). Data ini menunjukkan bahwa hasil intervensi tindakan telah melebihi persentase kenaikan minimal dan KKM indikator pencapaian kompetensi yang telah ditetapkan.

Paparan di atas menunjukkan bahwa penerapan metode latihan dapat meningkatkan kemampuan menulis puisi pada siswa. Metode latihan yang diberikan menambah penguasaan kosa kata dan memberi pemahaman yang mendalam kepada 
Peningkatan Kemampuan ...

Neneng Eliana

siswa kelas III Sekolah Dasar Negeri

16 Panjak dalam menulis puisi dengan baik, sehingga dapat meningkatkan kemampuan menulis puisi pada siswa dengan peningkatan rata-rata skor sebesar 5,87 pada asesmen awal menjadi sebesar 9,05 pada asesmen akhir. Hasil penelitian dapat dilihat pada tabel dan grafik berikut.

Tabel 3. Rekapitulasi Hasil Asesmen Kemampuan Menulis Puisi melalui Metode Latihan di Kelas III SDN 16 Panjak

\begin{tabular}{|c|l|c|c|c|}
\hline \multirow{2}{*}{ No } & \multirow{2}{*}{ Aspek Penilaian } & \multicolumn{3}{|c|}{ Rata-rata Skor/Aspek } \\
\cline { 3 - 5 } & & Asesmen Awal & Siklus I & Siklus II \\
\hline 1 & Tema & 1,972972973 & 2,888888889 & 3,378378378 \\
\hline 2 & Pengimajinasian & 1,945945946 & 2,777777778 & 2,891891892 \\
\hline 3 & Diksi & 1,945945946 & 2,555555556 & 2,783783784 \\
\hline Rata-rata Skor & 5,864864865 & 8,222222222 & 9,054054054 \\
Seluruh Aspek & $49 \%$ & $69 \%$ & $75 \%$ \\
\hline $\begin{array}{l}\text { Prosentase Rata-rata } \\
\text { Skor Seluruh Aspek }\end{array}$ & & & \\
\hline
\end{tabular}

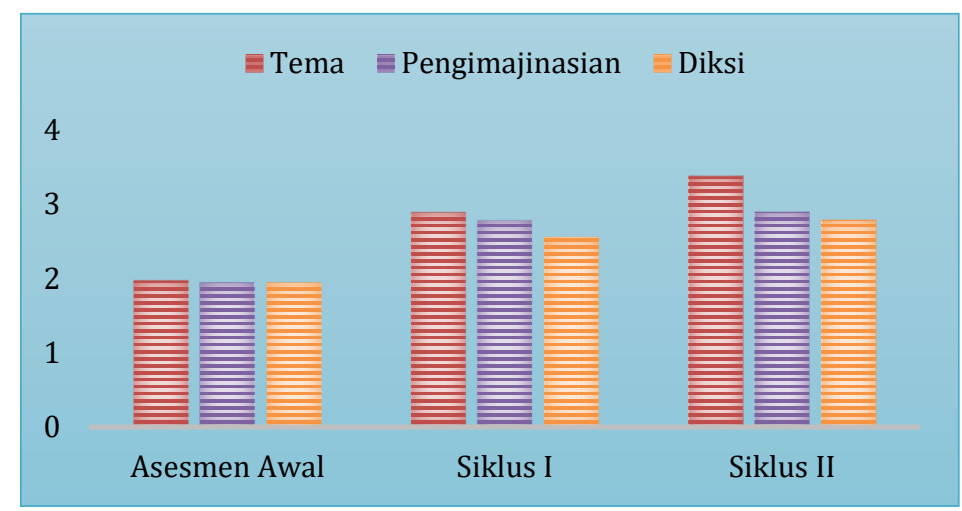

\author{
Diagram 3. Hasil Rata-rata Skor \\ Kemampuan Menulis Puisi \\ melalui Metode Latihan di Kelas III \\ Sekolah Dasar Negeri 16 Panjak
}




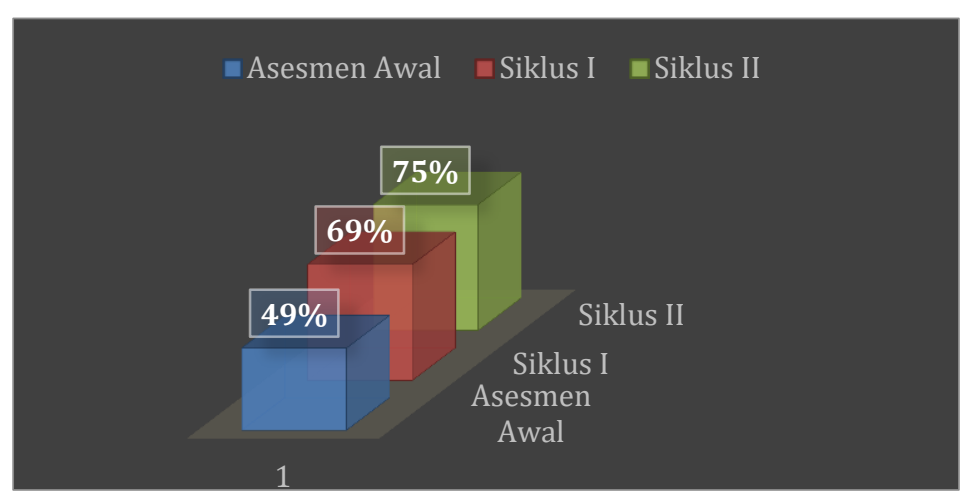

Diagram 4. Hasil Persentase Rata-rata Skor Kemampuan Menulis Puisi melalui Metode Latihan di Kelas III Sekolah Dasar Negeri 16 Panjak

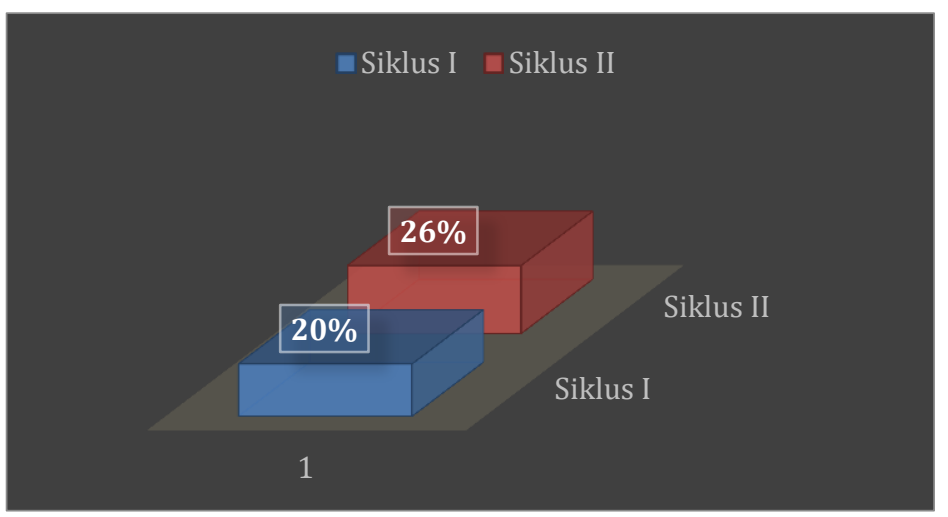

Diagram 5. Hasil Kenaikan Persentase Rata-rata Skor Kemampuan Menulis Puisi melalui Metode Latihan di Kelas III Sekolah Dasar Negeri 16 Panjak

\section{KESIMPULAN}

Berdasarkan temuan dan pembahasan maka hasil penelitian tindakan "Peningkatan Kemampuan Menulis Puisi melalui Metode Latihan" di Sekolah Dasar Negeri 16 Panjak, Dusun Panjak, Desa Sahan, Kecamatan Seluas, Kabupaten Bengkayang, Provinsi Kalimantan Barat ditarik kesimpulan: ditingkatkan melalui pembelajaran bahasa Indonesia dengan menggunakan metode latihan, (2) metode latihan dapat meningkatkan kemampuan menulis puisi pada siswa dengan peningkatan rata-rata skor sebesar 5,87 pada asesmen awal menjadi 9,05 pada asesmen akhir dari skor maksimal 12.

kemampuan menulis puisi dapat 
SARAN

Saran yang dapat dikemukakan terkait penelitian ini adalah diterapkannya metode latihan oleh guru di Sekolah Dasar Negeri 16 Panjak maupun sekolah lain sebagai salah satu upaya guru dalam

\section{DAFTAR PUSTAKA}

Anitah W, Sri, dkk. 2009. Strategi Pembelajaran di SD. Jakarta: Universitas Terbuka.

Hamalik, Oemar. 2008. Perencanaan Pengajaran Berdasarkan Pendekatan Sistem. Jakarta: Bumi Aksara.

Hensey, Paul. 1966. Management of Organization Behavior. USA: Prentice Hall Inc.

Jasin, HB. 1967. Tifa Penyair dan Daerahnya. Jakarta: Pustaka Jaya.

Kemmis, Stephen \& Robin McTaggart. 1988. The Action Research Planner. Viktoria: Deakin University.

Kurikulum Tingkat Satuan Pendidikan. 2006. Jakarta: Depdiknas.

Kurniawan, Heru. 2005. Sastra Anak. Yogyakarta: Graha Ilmu.

M.Gagne, Robert dan Liskie .J.Briggs. 1979. Principle of Instructional Design. menumbuhkan minat siswa terhadap pelajaran bahasa Indonesia, khususnya dalam menulis puisi dan dalam upaya guru meningkatkan kemampuan menulis puisi pada siswa.

NewYork: Holt Rinehart and Winston.

Mulyana, Slamet. 1955. Peristiwa Bahasa dan Sastra. Bandung: Ganaco.

Mulyati, Yeti. 2007. Keterampilan Berbahasa Indonesia SD. Jakarta: Universitas Terbuka.

Popham, W.James dan Eva L. Baker. 2005. Teknik Mengajar Secara Sistematis terjemahan Amirul Hadi dkk. Jakrta: Rineka Cipta.

Roestiyah, N.K. 2001. Strategi Belajar Mengajar. Jakarta: Rineka Cipta.

Rosdiana, Yusi, dkk. 2009. Bahasa dan Sastra Indonesia di SD. Jakarta: Universitas Terbuka.

Sanjaya, Wina. 2006. Strategi Pembelajaran Berorientasi Standar Proses Pendidikan. Jakarta: Kencana Prenada Media Group.

Semiawan, Conny, A.S.Munandar dan S.C. Utami Munandar 1990. Memupuk Bakat dan Kreativitas Siswa Sekolah Menengah (Petunjuk Bagi 
Guru dan Orang Tua). Jakarta: Gramedia.

Situmorang, BP. 1981. Puisi: Teori, Apresiasi Bentuk dan Struktur. Ende - Flores Nusa Indah.

Sudjana, Nana. 2008. Dasar-Dasar Proses Belajar Mengajar. Bandung: Sinar Baru Algensindo.

Sukardi. 2011. Metodologi Penelitian Pendidikan, Kompetensi dan Praktiknya. Yogyakarta: Bumi Aksara.

Tarigan, Djogo, dkk. 2004. Pendidikan Bahasa dan
Sastra Indonesia di Kelas Rendah (cetakan kedua belas). Jakarta: Universitas Terbuka.

$\begin{array}{cr}2006 . & \text { Pendidikan } \\ \text { Keterampilan } & \text { Berbahasa. } \\ \text { Jakarta: Universitas Terbuka. }\end{array}$

Yunus, Mohamad dan Suparno. 2008. Keterampilan Dasar Menulis. Jakarta: Universitas Terbuka.

KBBI, Daring. 2008. Memeras. Retrieved April 21, 2015 http://pusatbahasa.depdiknas. go.id/kbbi/index.php 